\title{
Immunotherapy in the treatment of colorectal cancer: a new kid on the block
}

\begin{abstract}
Andrea Spallanzani, Fabio Gelsomino, Francesco Caputo, Chiara Santini, Kalliopi Andrikou, Giulia Orsi, Margherita Rimini, Stefania Pipitone, Laura Riggi, Camilla Bardasi, Massimiliano Salati, Stefano Cascinu
\end{abstract}

Division of Oncology, University Hospital of Modena, Modena 41124, Italy.

Correspondence to: Dr. Andrea Spallanzani, Division of Oncology, University Hospital of Modena, Via del Pozzo 71, Modena 41124, Italy. E-mail: andrea.spallanzani@unimore.it

How to cite this article: Spallanzani A, Gelsomino F, Caputo F, Santini C, Andrikou K, Orsi G, Rimini M, Pipitone S, Riggi L, Bardasi C, Salati M, Cascinu S. Immunotherapy in the treatment of colorectal cancer: a new kid on the block. J Cancer Metastasis Treat 2018;4:28. http://dx.doi.org/10.20517/2394-4722.2018.31

Received: 13 May 2018 First Decision: 29 May 2018 Revised: 1 Jun 2018 Accepted: 6 Jun 2018 Published: 19 Jun 2018

Science Editor: Guofeng Xie Copy Editor: Jun-Yao Li Production Editor: Huan-Liang Wu

\begin{abstract}
In the last few years, the success of anti-PD1 and anti-PDL1 drugs in solid cancers treatment and the advances in molecular biology have provided new potential treatment strategies for patients with metastatic colorectal cancer. Unfortunately, only patients with mismatch repair deficiency seem to benefit from immunotherapy and they represent a small subset of the metastatic population. New ongoing studies focus on converting an immune ignorant tumour into an inflamed one by combination therapies and on introducing an immunotherapeutic approach in earlier stages of disease (neoadjuvant and adjuvant setting). In this review we summarize the current knowledge about the molecular and immune landscape of colorectal cancer and propose new potential combination strategies to enhance the efficacy of immunotherapy.
\end{abstract}

Keywords: Colorectal cancer, immunotherapy, microsatellite instability, pembrolizumab, nivolumab, atezolizumab

\section{INTRODUCTION}

Colorectal cancer (CRC) is the third most common cancer in males and the second in females, representing the fourth leading cause of cancer-related deaths worldwide in older adults ${ }^{[1,2]}$.

However, CRC-related mortality has declined progressively in the past decades, due to cancer screening programs, standardization of preoperative and postoperative care, improved surgical techniques and moreeffective systemic therapies for early and advanced-stage disease ${ }^{[3]}$.

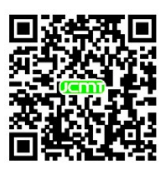


Nevertheless, about $50 \%$ of patients develops metastases during the course of their disease. In these patients, chemotherapy (fluoropyrimidines, oxaliplatin and irinotecan) with biological agent [anti-vascular endothelial growth factor (anti-VEGF), anti-epithelial growth factor receptor (anti-EGFR) and multikinase inhibitor such as regorafenib] remains the standard of care, with median overall survival approaching 30 months ${ }^{[4]}$.

The molecular characterization of colorectal cancer has led to the identification of favorable and unfavorable immunological features linked to clinical outcome ${ }^{[5]}$.

Currently, CRC is classified into four consensus molecular subtypes (CMS), with unique clonal, stromal and immune dependences ${ }^{[6]}$.

The immune system has a substantial effect on cancer, especially as a suppressor of tumour initiation and progression. Additionally, it influences the response to immunotherapeutic and conventional treatment options (e.g., chemotherapy, radiotherapy and targeted therapies). However, the tumor can establish several mechanisms to escape immune surveillance. Therefore, different strategies may be pursued to restore the immune response against cancer cells, both as an active immunotherapy (cytokines, immune checkpoint inhibitors, co-stimulatory pathways and cancer vaccines) and as a passive immunotherapy (adoptive cellular therapy and monoclonal antibodies) approach ${ }^{[7]}$. FDA has recently approved checkpoint inhibitors (nivolumab and pembrolizumab), for the treatment of patients with microsatellite instability (MSI) metastatic CRC. However, the most unsolved problem is the lack of efficacy of these antibodies in microsatellites stable (MSS) tumours, which represent the majority of CRC.

In this review we summarize the biological bases and the recent clinical evidences related to the use of immunotherapy in metastatic colorectal cancer (mCRC) to suggest different treatment strategies according to different CMS, transcriptomic pathways and stroma-immune microenvironment.

\section{RATIONALE FOR IMMUNOTHERAPY IN CRC}

The immune system has a major role in cancer: immune cells can act both as suppressors of tumor initiation and progression and as promoters of proliferation, infiltration and metastasis.

In 1970 Burnet $^{[8]}$ proposed the concept of immune-surveillance, that was updated by Dunn et al..$^{[9]}$ and Schreiber et al. ${ }^{[10]}$ with the identification of the process of immunoediting. This process consists of three well-defined phases: elimination, equilibrium and escape. The elimination phase refers to active surveillance, and includes innate and adaptive immune responses to tumour cells. First of all, cells of the innate immune system (NK cells, NK T cells, macrophages and dendritic cells) recognize the presence of a growing tumor after its stromal remodeling, a local tissue damage and the release of inflammatory signals, which recruit these cells to the tumor site. They produce IFN-gamma and IL-12, and destroy most of cancer cells, even if some of them survive and reach the "equilibrium" phase. Therefore, in the elimination phase, the release of IFN-gamma and production of chemokines as CXCL10, CXCL9 and CXCL11 determine the inhibition of angiogenesis. Meanwhile dendritic cells migrate into the draining lymph nodes and promote the differentiation of Th1 cells into cytotoxic CD8+ T cells. In the equilibrium phase tumor cells that have escaped the elimination phase and have a non-immunogenic phenotype are selected for growth. Progressively these cells become unstable and acquire various mutations, so they will be able to grow despite immune attack and reach the escape phase. In this third phase, tumor cells continue to grow and may lead to malignancies.

In this process we can identify three main characters ${ }^{[11]}$ :

1. Tumour cells have several mechanisms that block the activity of effector antitumor CD4+ and 
$\mathrm{CD} 8+\mathrm{T}$ cells, in order to reduce local tumour-infiltrating immune responses. Frequent mechanisms include loss of MHC class I expression, dysregulation of antigen processing machinery, production of immunosuppressive factors (TGF-beta; IL-10; VEGF; indoleamine 2,3 dehydrogenase), recruitment of immunosuppressive cells (i.e T-reg) ${ }^{[12]}$ and activation of negative costimulatory signals in tumour microenvironment like PD-L1 ${ }^{[13]}$.

2. Tumour microenvironment consists of regulatory immune cells, extracellular matrix proteins, and fibroblasts (cancer-associated fibroblasts, CAFs). They secrete tumour-promoting factors that contribute to tumor invasion and neoangiogenesis ${ }^{[14]}$. CAFs play a critical role in CRC immunosuppression, particularly in CRC RAS mutated; in fact they lead to tumour progression by activating epithelial mesenchymal transition and TGF-beta/SMAD signalling ${ }^{[15]}$ : high levels of CAFs markers are correlated with poor prognosis in $\mathrm{CRC}^{[16]}$.

3. The immune system includes innate and adaptive immune cells. The innate cells consist of macrophages, mast cells, neutrophils, dendritic cells, and myeloid-derived suppressor cells (MSDCs) and natural killer (NK) cells. The adaptive T cells include CD8+ cytotoxic T lymphocytes (CTLs), CD4+ Th1 cells, CD4+ Th17 cells and regulatory $\mathrm{T}$ cells (Tregs) ${ }^{[7]}$. A strong lymphocytic infiltration is associated with better clinical outcome in many tumors, including colorectal cancer. Particularly, high densities of $\mathrm{CD} 3+\mathrm{T}$ cells, $\mathrm{CD} 8+$ cytotoxic $\mathrm{T}$ cells and $\mathrm{CD} 45 \mathrm{RO}+$ memory $\mathrm{T}$ cells are associated with a longer disease free survival (DFS) and improved overall survival (OS $)^{[17]}$. Therefore in CRC also the infiltration of M1 macrophages, DCs and NK cells is associated with good prognosis, while the presence of M2 macrophages, MDSCs, Th17 and B cells is related with poor outcome ${ }^{[18]}$.

All these findings have been translated into the elaboration of the so called "immunoscore". It is based on the quantification of two lymphocytes populations (CD3/CD45RO, CD3/CD8 or CD8/CD45RO) in both tumor core and invasive margin. It ranges from o (low density of both cells in both cancer regions) to 4 (high density) and may predict DFS and OS in $\mathrm{CRC}^{[19]}$. It may help identify patients with early stage disease who might benefit from adjuvant chemotherapy or immunotherapies according to T-cell densities ${ }^{[20]}$.

\section{FROM MOLECULAR SUBTYPES TO STROMAL CLASSIFICATION}

The development of CRC is supported by the accumulation of genetic and epigenetic alterations that transform colonic epithelial cells into colon adenocarcinoma cells. The genomic instability occurs early in carcinogenesis and it facilitates the acquisition of alterations in tumour suppressor genes and oncogenes in a clone of cells, resulting in cancer ${ }^{[21,22]}$. Three fundamental pathways are implicated in this process:

1. Chromosomal instability (CIN): CIN is observed in the majority of sporadic CRCs (65\%-75\%) and is characterized by a variety of chromosomal alterations leading to defects in chromosomal segregation, telomere stability, and the DNA damage response as well as a loss of heterozygosity. CIN-high tumours typically accumulate mutations in specific tumor-suppressor genes and oncogenes that activate critical pathways for CRC pathogenesis, including KRAS, CTNNB1, PIK3CA, APC, TP53 and SMAD4.

2. CpG-island methylator phenotype (CIMP): it is defined by hypermethylation of the symmetrical dinucleotide $\mathrm{CpG}$ and a global DNA hypomethylation. In many human genes there's a CpG island in their promoter region, and the methylation of the cysteines of the CpG-island implicates the transcriptional silencing of the gene ${ }^{[23]}$. When this happens in promoters of tumour suppressor genes, it supports the possible development of cancer ${ }^{[24]}$.

3. Microsatellite instability (MSI): it occurs in $15 \%$ of early-stage colorectal tumors. It is caused by a lack of expression in the DNA mismatch repair (dMMR) proteins, which normally are involved in the correction of DNA replication errors. This defect results in accumulation of mistakes in microsatellite regions, which are short repetitive sequences of DNA, with unit length ranging from one to six bases. They are scattered throughout the coding and noncoding regions of the genome. MSI can be due 
to germline mutations of MMR enzymes, as MLH1, MSH2, MSH6, and PMS2, which causes the so called Lynch syndrome ${ }^{[25-27]}$. There are also sporadic dMMR CRCs, which arise mainly from epigenetic silencing of MLH1 promoter, and they are associated with CIMP phenotype and BRAF V600E mutations.

To define MSI, five microsatellites are evaluated trough PCR based assay: if $\geq 2 / 5$ are unstable, the sample is defined as MSI-high (MSI-H), while 1/5 or 0/5 are MSI-low (MSI-L) and MSS, respectively, which have a similar behavior ${ }^{[28]}$.

The progressive findings in the molecular characterization of CRC along with the identification of specific gene alterations as prognostic and predictive factors in this cancer, led to the elaboration of various CRC classifications, essentially based on gene expression ${ }^{[29-33]}$. However, there were many differences among these classifications, so in 2015 the CRC Subtyping Consortium (CRCSC) developed a new classification, identifying four consensus molecular subtypes (CMS), analyzing the results of six CRC subtyping algorithms ${ }^{[34]}$. Each CMS group had a specific pattern:

- CMS1 (MSI Immune, 14\%): CMS1 samples were hypermutated, with low prevalence of somatic copy number alterations (SCNAs), enriched of MSI and CIMP tumours with hypermethylation status. A particular characteristic of this group was a more frequent presence of BRAF mutations, compared to the other CMS. This subtype was defined as immune, because of the rich immune infiltrate (especially Th1, cytotoxic T cells and NK cells) and the strong activation of immune evasion pathways, as we typically see in MSI CRC ${ }^{[35]}$.

- CMS2 (Canonical, 37\%): this group exhibited the typical CIN pattern; it also showed more frequent copy number gains in oncogenes and losses in tumour suppressor genes. It was characterized by epithelial differentiation, with WNT and MYC activation, higher expression of the oncogenes EGFR, ERBB2 (also known as HER2), insulin-like growth factor 2 (IGF2), insulin receptor substrate 2 (IRS2) and transcription factor hepatocyte nuclear factor $4 \alpha(H N F 4 A)$, as well as cyclins2.

- CMS3 (Metabolic, 13\%): CMS3 samples were characterized by few SCNAs, a 30\% significant hypermutation with a mixed MSI status, a higher prevalence of CIMP low cluster and an intermediate hypermethylation status. This subtype was defined as "metabolic" according to the common metabolic alterations and the higher expression of KRAS mutations, which made this group of cancers similar to a recently identified gastric cancer subtype ${ }^{[12]}$.

- CMS4 (Mesenchymal, 23\%): similarly to CMS2, this group had a high prevalence of SCNAs. It showed the typical mesenchymal pattern, as the upregulation of genes involved in epithelial mesenchymal transition, the TGF $\beta$ activation, angiogenesis, matrix remodeling, with a consequent stromal infiltration, particularly CAFs.

This classification reflects also significant clinical and prognostic differences among the various subtypes: CMS1 cancers are frequent in females with right-sided tumours and have a higher histopathological grade, while CMS2 cancers are more frequently left-sided. Moreover, CMS4 cancers are often diagnosed at advanced stages and they show worse overall survival (OS) and relapse-free survival (RFS). Patients with the typical CMS1 pattern have poor survival after relapse, consistently with the known bad prognosis of patients with MSI and BRAF mutated CRC after relapse ${ }^{[36]}$, differently from CMS2 population, which has the best survival after relapse of these CMS groups ${ }^{[37,38]}$.

\section{IMMUNOTHERAPY IN MSI MCRC}

Mismatch repair deficient CRCs represent 15\% to 20\% of stage II and III CRCs and are associated with better prognosis than proficient (pMMR) tumors. In the metastatic setting, dMMR CRCs represent only around 5\% and are associated with a poor prognosis ${ }^{[39]}$, as confirmed in the recent results presented at the 2017 ASCO 
meeting (OS at 17.9 months and PFS at 3.9 months), whatever the chemotherapy regimen or targeted therapy used (bevacizumab or anti-EGFR) ${ }^{[40]}$.

Actually, immunotherapy is a prominent therapeutic approach in many cancers, such as melanoma, nonsmall cell lung cancer, kidney and bladder cancer. However, significant advances have been made also in CRC. A first study utilizing a CTLA-4 antagonist monoclonal antibody, tremelimumab, showed a possible usefulness of immune checkpoint inhibitors in CRC, obtaining one 6-month durable response ${ }^{[41]}$.

Then, in the phase II trial conducted by Le et al. ${ }^{[42]}$, the clinical activity of pembrolizumab was evaluated in three cohorts of patients: MSI-H CRC, MSI-H non CRC, and MSS CRC. The immune-related objective response rate (ORR) and the immune-related 6-month PFS rate were $40 \%$ and $78 \%$, respectively, in the dMMR CRC patients, $0 \%$ and $11 \%$ in the pMMR CRC patients. These findings currently are being evaluated in the KEYNOTE-177 phase III trial in patients with dMMR metastatic CRC who have been randomized to treatment with pembrolizumab $v s$. standard therapy.

In Checkmate 142, nivolumab alone and the combination of nivolumab + ipilimumab were evaluated in patients with metastatic CRC, with or without MSI. Seventy patients with MSI-H CRC were enrolled and treated with nivolumab monotherapy ( $3 \mathrm{mg} / \mathrm{kg}$ every 2 weeks). At the preliminar presentation of the trial results, of the 47 patients which had at least 12 weeks of follow-up, 26\% had an objective response while 30\% had stable disease, with disease control rate of 55\%. In the update published on Lancet, 23 of 74 patients achieved an objective response (ORR 31\%) and 51 of 74 patients had disease control for 12 weeks or longer $(\mathrm{DCR} 69 \%)^{[43]}$. By the use of combination therapy (nivolumab $3 \mathrm{mg} / \mathrm{kg}$ q2 week plus ipilimumab $1 \mathrm{mg} / \mathrm{kg}$ q3 week $\times 4$ doses, followed by nivolumab monotherapy), investigator-assessed ORR was $55 \%$, and disease control rate for $\geq 12$ weeks was $80 \%{ }^{[44]}$. In this heavily pre-treated population, 12 months overall survival was $73 \%$ and $85 \%$ with monotherapy and combination therapy respectively. Grade 3 and 4 drug related adverse events (AEs) were reported in 25 patients treated with nivolumab (20\%) mainly asymptomatic increasing of amylases and lipase: only 5 patients (7\%) stopped the treatment due to toxicities. In the combination group, grade 3 and 4 AEs were reported in 32\% of patients: 15 patients (13\%) discontinued treatment because of study drug-relates AEs.

All these data supported the benefit of immunotherapy in MSI-H CRC, and for this reason FDA approved the use of nivolumab and pembrolizumab in patients with unresectable or metastatic MSI-H and dMMR CRC, that have progressed after previous treatment.

Similar results were not reached in MSS CRC, in fact in the pivotal pembrolizumab study, no response was achieved, with very poor PFS and OS, as subsequently confirmed in other trials ${ }^{[45,46]}$ [Table 1].

There are several combination clinical trials and novel immunotherapeutic strategies under active investigation for metastatic CRC [Table 2].

\section{STRATEGIES TO CONVERT AN IMMUNE IGNORANT TUMOR INTO AN INFLAMED ONE}

There are mainly 3 different tumour immune phenotypes [Figure 1]:

1. Highly immune-infiltrated tumours with favourable immune microenvironment, enriched of Th1-type functional TILs;

2. Highly immune-infiltrated tumours with unfavourable tumour microenvironment with active angiogenic and immunosuppressive pathways;

3. Poorly immunogenic tumours with minimal immune cell infiltration ${ }^{[47]}$. 
Table 1. Immunotherapy trials in metastatic colorectal cancer

\begin{tabular}{|c|c|c|c|c|}
\hline Population & Drugs & Target & Patients & Response rate \\
\hline \multirow[t]{7}{*}{ Refractory MSI-H CRC } & Pembrolizumab (42) & PD-1 & 25 & $57 \%$ \\
\hline & & & & Sporadic cases:100\% $(n=6 / 6)$ \\
\hline & & & & LS cases: $27 \%(n=3 / 11)$ \\
\hline & Nivolumab (43) & PD-1 & 74 & $31 \%$ \\
\hline & & & & Sporadic cases: $36 \%(n=10 / 36)$ \\
\hline & & & & LS cases: $30 \%(n=8 / 27)$ \\
\hline & Nivolumab + ipilimumab (44) & PD-1 + CTLA-4 & 119 & $55 \%$ \\
\hline \multirow{2}{*}{$\begin{array}{l}\text { Refractory } \\
\text { MSS CRC }\end{array}$} & Pembrolizumab (42) & PD-1 & 28 & $0 \%$ \\
\hline & Nivolumab + ipilimumab (44) & PD-1 + CTLA-4 & 20 & $5 \%$ \\
\hline \multirow[t]{7}{*}{ Refractory CRC } & Tremelimumab (41) & CTLA-4 & 49 & $2 \%$ \\
\hline & Nivolumab (45) & PD-1 & 19 & $0 \%$ \\
\hline & BMS-936559 (46) & PD-L1 & 18 & $0 \%$ \\
\hline & Atezolizumab + bevacizumab (49) & PD-L1 & 14 & $7 \%$ \\
\hline & $\begin{array}{l}\text { Atezolizumab + FOLFOX/bevacizumab, } \\
70 \% \text { firstline (49) }\end{array}$ & PD-L1 & 30 & $\begin{array}{l}40 \% \text { (total) } \\
48 \% \text { (first-line) }\end{array}$ \\
\hline & Atezolizumab + cobimetinib (53) & PD-L1 MEK & 23 & $17 \%$ \\
\hline & & & & (3 MSS, 1 unknown) \\
\hline
\end{tabular}

CRC: colorectal cancer; CTLA-4: cytotoxic T lymphocyte associated antigen 4; PD-L1: programmed cell death ligand-1; PD-1: programmed cell death protein 1; MSS: stable microsatellite; MSI-H: high microsatellite instability

Table 2. Ongoing studies in colorectal cancer

\begin{tabular}{|c|c|c|c|}
\hline Trial & Treatment & Patient population & Endpoints \\
\hline $\begin{array}{l}\text { Keynote-177 } \\
\text { NCT02563002 }\end{array}$ & $\begin{array}{l}\text { Pembrolizumab monotherapy } \\
\text { vs. standard care } \\
\text { chemotherapy }\end{array}$ & $\begin{array}{l}\text { MSI-H CRC, } \\
\text { 1st line metastatic }\end{array}$ & PFS \\
\hline $\begin{array}{l}\text { Keynote-164 } \\
\text { NCT02460198 }\end{array}$ & Pembrolizumab monotherapy & $\begin{array}{l}\text { MSI-H CRC, metastatic refractory } \\
\text { (Cohort A) or } \geq 1 \text { prior therapy } \\
\text { (Cohort B) }\end{array}$ & ORR \\
\hline $\begin{array}{l}\text { NRG-GI004/S1610 } \\
\text { NCT02997228 }\end{array}$ & $\begin{array}{l}\text { Atezolizumab vs. atezolizumab + } \\
\text { FOLFOX + bevacizumab vs. } \\
\text { FOLFOX + bevacizumab }\end{array}$ & $\begin{array}{l}\text { MSI-H CRC, } \\
\text { 1st line metastatic }\end{array}$ & PFS \\
\hline $\begin{array}{l}\text { Alliance A021502 } \\
\text { NCT02912559 }\end{array}$ & $\begin{array}{l}\text { Atezolizumab + FOLFOX vs. FOLFOX } \\
\text { alone }\end{array}$ & MSI-H CRC, stage III & DFS \\
\hline NCT02870920 & $\begin{array}{l}\text { BSC + durvalumab + tremelimumab vs. } \\
\text { BSC }\end{array}$ & MSS, chemorefractory $\mathrm{mCRC}$ & OS \\
\hline NCT02788279 & $\begin{array}{l}\text { Atezolizumab vs. atezolizumab + } \\
\text { cobimetinib vs. regorafenib }\end{array}$ & Chemorefractory $\mathrm{mCRC}$ & OS \\
\hline $\begin{array}{l}\text { NCT02873195 } \\
\text { BACCI study }\end{array}$ & $\begin{array}{l}\text { Atezolizumab + capecitabina }+ \\
\text { bevacizumab }\end{array}$ & Chemorefractory $\mathrm{mCRC}$ & PFS \\
\hline NCT02948348 & Nivolumab + chemoradiotherapy & Locally advanced CRC & $\begin{array}{l}\text { Pathological complete } \\
\text { response }\end{array}$ \\
\hline NCT02888743 & $\begin{array}{l}\text { Durvalumab + tremelimumab +/- } \\
\text { radiation }\end{array}$ & Chemorefractory $\mathrm{mCRC}$ & ORR \\
\hline
\end{tabular}

CRC: colorectal cancer; MSS: stable microsatellite ; MSI-H: high microsatellite instability; BSC: best supportive care; PFS: progression free survival; OS: overall survival; DFS: disease free survival; ORR: overall response rate

CMS1 tumours are characterized by upregulation of PD-1, PDL-1, CTLA-4 and IDO as described above and so they are the best candidates for immunotherapy.

A major challenge is to render pMMR mCRC (second and third group descripted above) sensitive to immune checkpoint inhibitors. In the pivotal pembrolizumab trial by Le et al. ${ }^{[42]}$, no responses in the MSS CRC pretreated cohort were observed with median overall survival of 5 months. Furthermore in the "combo" experience Checkmate 142 with nivolumab and ipilimumab, only 1 response was observed among 20 patients with pMMR CRC ${ }^{[44]}$.

CMS4 tumours should be considered "hot tumours" with immunosuppressive signalling ongoing: 


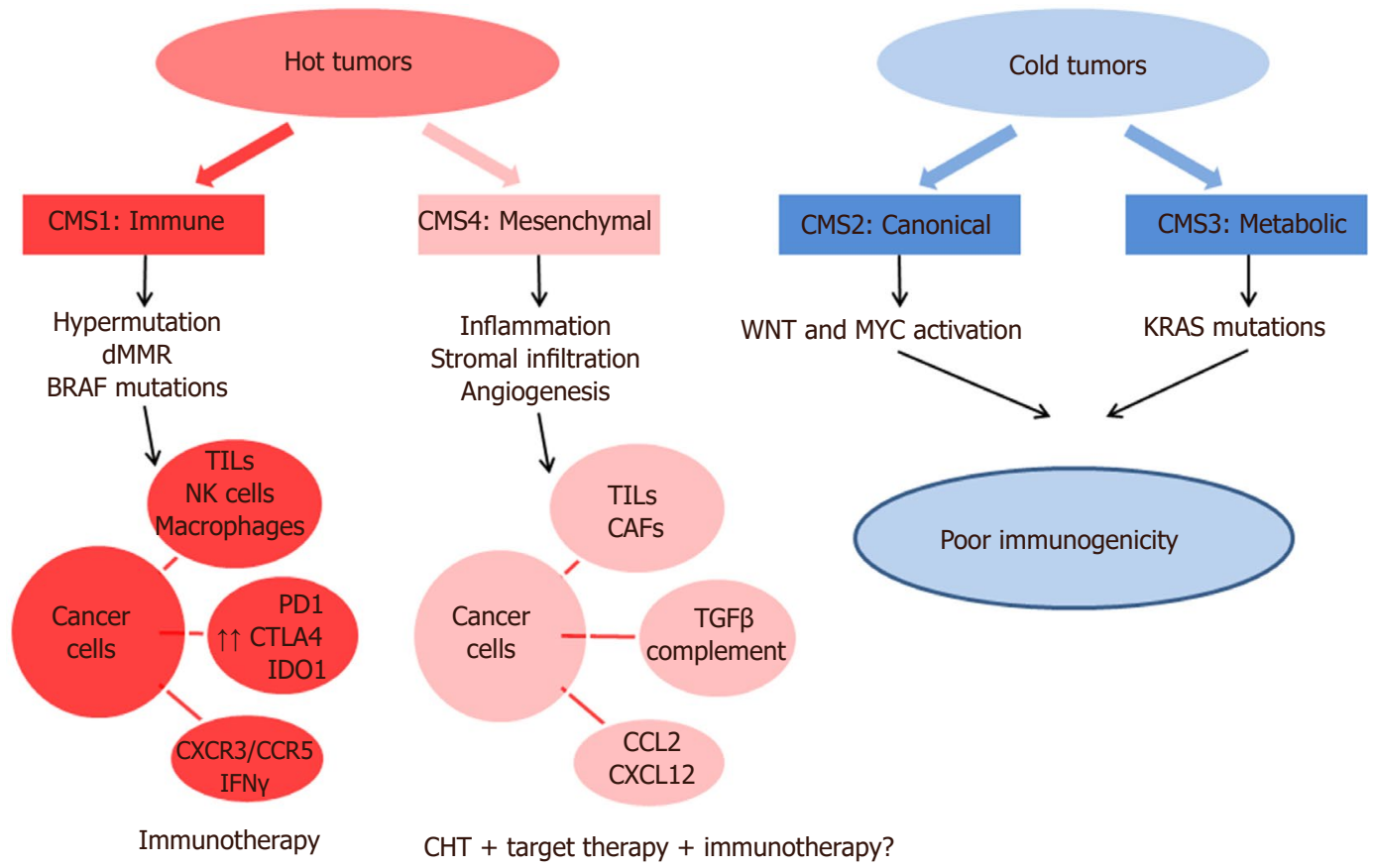

Figure 1. Immune subtypes classification. CMS: Consensus molecular subytpe; dMMR: deficit mismatch repair; TILs: tumor-infiltrating lymphocytes; PD1: programmed death protein 1; CTLA4: cytotoxic T-lymphocyte-associated protein 4; IDO1: indoleamine-pyrrole 2,3-dioxygenase; IFN $\gamma$ : interferon gamma; CXCR3-CCR5: chemokine receptor type 3-5; CAFs: cancer associated fibroblasts; TGFB: transforming growth factor beta; CCL2-CXCL12: chemokin ligand 2-12

TGF-B signalling and an angiogenic microenvironment should be targeted to restore a "CMS-1-like" immune microenvironment. Preclinical data suggested a synergic effect of TGF-B and PD-1 inhibition in mouse model of mesenchymal $\mathrm{CRC}^{[48]}$. The role of chemotherapy alone in CMS4 tumours is ambiguous: chemotherapy has a detrimental effect on the immune system but the cell-necrosis inducted and the subsequent release of neo antigens should be immunogenic, promoting the activity of APC and thus an immune-response. Based on previous clinical data suggesting an adjuvant immune effect of antiVEGF antibody combined with standard chemotherapy, the combination of FOLFOX, bevacizumab and atezolizumab has been evaluated in a cohort of 23 naïve patients. Almost all patients demonstrated clinical benefit with $11(48 \%)$ achieving partial response and $9(40 \%)$ stable disease: how these results should be interpreted is still unclear but the clinical benefit reached in almost $90 \%$ of patients deserves further investigations ${ }^{[49,50]}$. Several other clinical trials investigating the combination of chemotherapy, bevacizumab and check-point inhibitors are ongoing.

CMS2 and CMS3 tumours are typically "cold tumours" with downregulation of MHC class I and lack immune cell infiltration ${ }^{[47]}$. A lot of strategies are still under evaluation to convert these immune-ignorant tumours into "hot tumours".

In preclinical experiences, $\mathrm{MEK}$ and $\mathrm{PD}-1$ co-inhibition showed a synergistic effect in colorectal, melanoma and breast cancer models ${ }^{[51]}$. Cobimetinib, a MAPK inhibitor, upregulates IFN-gamma, HLA molecules and PDL-1 expression stimulating CD8+ CTLs activity in the tumour microenvironment ${ }^{[52]}$.

Based upon these preclinical data, a phase I study that combined MEK and PDL-1 inhibition (cobimetinib and atezolizumab) was designed in which 4 of the 23 patients enrolled achieved partial response(17\%): 3 of these 4 patients were pMMR, 1 had an unknown MSI/MMR status ${ }^{[53]}$. Actually, a three arms phase III study in which patients with pMMR chemo-refractory CRC are randomized to receive atezolizumab, or a 
combination of atezolizumab and cobimetinib or regorafenib has completed the accrual and its results are eagerly awaited.

Another strategy to inflame these "cold cancers" could be enhancing T cell infiltration, typically poor in these tumors. Histone deacetylase (HDAC) inhibitors like romidepsin (preclinically tested for this capacity) have been actually combined with anti-PD1 therapy in a phase I/II trial currently ongoing in $\mathrm{CRC}^{[54]}$.

Another option could be the use of BITEs (Bispecific T cell engager) that bind the CD3 subunit of the T cell receptor and a tumor specific antigen.

Interesting results from preclinical experiences ${ }^{[55]}$ lead to a phase I trial with CEA-CD3 TCB (RG7802, RO6958688). CEA-CD3 TCB is a novel T-cell bispecific antibody targeting CEA on tumour cells and CD3 on $\mathrm{T}$ cells increasing intratumoral $\mathrm{T}$ cell infiltration and activation and enhancing the PD-L1/PD-1 pathway ${ }^{[56]}$.

The phase I trial results, presented at ASCO 2017 by Tabernero et al ${ }^{[57]}$, suggested antitumor activity in monotherapy and enhanced efficacy in combination with atezolizumab in patients with advanced CEA+ solid cancers with manageable safety profile.

\section{COMBINATIONS WITH RADIOTHERAPY}

Radiotherapy determines cell death in targeted lesions inducing local and systemic immune-mediated antitumour effects. In 1953, Mole ${ }^{[58]}$ proposed the term "abscopal effect" referring to the effects of ionizing radiation at a distance from the irradiated volume but within the same organism. Almost 50 years later, the role of the immune system in this "off target" effect has been settled. RT may affect antitumor immunity by enhancing antigen presentation by upregulation of major histocompatibility complex class I (MHC1) expression of malignant cells and upregulation of tumor-associated antigens ${ }^{[59]}$. The clinical use of immune checkpoint inhibitors has greatly increased the number of abscopally responding patients. In a preclinical trial, Park et al. ${ }^{[60]}$ achieved complete regression of primary tumour and partial response in distant metastases via abscopal responses with combination of radiotherapy and anti-PD1. At ASCO 2016, preliminary results of a phase II trial evaluating the abscopal effects of pembrolizumab after liver radiofrequency ablation or external beam radiotherapy had been presented. Tolerable safety profile and a partial response in non-irradiated lesions over 23 patients treated have been demonstrated ${ }^{[61]}$. A phase II trial investigating the efficacy of durvalumab-tremelimumab in combination with radiotherapy in patients with liver limited disease is underway (NCT02888743).

Trials with long-course chemoradiation in combination with PD-1 inhibition in locally advanced rectal cancer are still ongoing and so answers about this approach should be available in the next few years (NCT02948348, NCT03038477).

\section{IMMUNOTHERAPY COMBINATIONS}

The clinical activity of epacadostat (IDO-inhibitor) alone appears limited but combination with pembrolizumab in melanoma patients reported ORR of $58 \%{ }^{[62,63]}$. Actually epacadostat has been investigated in combination with pembrolizumab and azacitidine in refractory MSS CRC.

Also cetuximab, an anti-EGFR antibody actually approved for treatment of pan-RAS wt colorectal cancer, demonstrated a T-cell response and antigen liberation in HNSCC; in MCRC patients treated with cetuximab a relevant intratumoral T-cell infiltrates has been shown ${ }^{[64]}$. For these reasons, an ongoing phase I-II trial is examining the role of cetuximab-pembrolizumab combination in mCRC. 


\section{OTHER STRATEGIES TO ENHANCE THE IMMUNOTERAPY EFFECT}

Other strategies are actually ongoing to enhance the response to immunotherapy ${ }^{[65]}$.

MGN1703 is a DNA-based Toll-like receptor that acts as an immunomodulator with immune activation in heavily pre-treated patients with mCRC in the phase II IMPACT trial in maintenance setting ${ }^{[66]}$. Patients who had completed first line standard chemotherapy + bevacizumab were randomly allocated to lefitolimod or placebo. There was a statistically significant better PFS in the experimental arm from start of induction therapy with the greatest benefit for patients with relatively low tumour burden ${ }^{[67]}$. Data on the use of MGN1703 (lefotolimod) as switch maintenance in patients with mCRC responding to first line chemotherapy are awaiting (Impala phase III trial).

In the perioperative liver-limited disease setting, the role of immunotherapy in association of chemotherapy was evaluated for the first time in 1996: a preoperative injection of IL-2 in patients with DUKES D tumours neutralized surgery-induced immunosuppression with improved overall survival due to postoperative mean numbers of T lymphocytes, natural killer cells and activated lymphocytes significantly higher in IL-2-treated patients than in controls ${ }^{[68]}$. Results from ongoing trials with check-point inhibitors also in this setting are awaited.

In the CRC prevention setting, the role of immunotherapy alone or in combination with chemotherapy is under evaluation. Vaccination is by far the first approach evaluated. Based on a MUC-1 vaccination clinical trial that enrolled 39 patients and suggested the presence of immunosuppressive mediators in premalignant stages $^{[69]}$, a multicenter randomized phase II trial for testing the efficacy of this vaccine is actually ongoing (NCT02134925). Therapeutic KRAS mutated vaccines have been tested in preclinical trials for advanced tumors $^{[70]}$.

Combinations of immune-modulating agents and chemopreventive drugs have been tested in preclinical studies $^{[71]}$. The synergic effect of combining a non-steroidal anti-inflammatory drug (NSAID) with an immune checkpoint inhibitor is supported by preclinical data: aspirin induced upregulation of PD-L1 and PD-L2 expression ${ }^{[72]}$.

In a trial by Zelenay et al ${ }^{[73]}$, the combination of COX-inhibitor and PD-1 inhibitor, was effective in eradicating BRAF-mutated melanoma neoplastic cells in mice with a significant increase in IFN, CXCL10, IL12 expression as immune-stimulating factors.

There are a lot of exogenous and endogenous factors (collectively called exposome) which are able to influence the development of CRC. However, for a comprehensive evaluation of tumor immunity, both the neoplastic cells and the immune system need to be deeply analyzed. Immune cells analyses in the tumor microenvironment have not been integrated into experimental immunological studies. In this regard, molecular pathological epidemiology (MPE) offers the opportunity to a multilevel research using bioinformatics and omics technologies to integrate immunology into population health sciences, providing a deeper understanding of the interaction between tumor, exposome and immune system and offering new insights for the development of intervention strategies, thus moving towards the era of precision medicine ${ }^{[74]}$. For example, the relation between microbiota and efficacy of chemotherapy and immunotherapy has been extensively evaluated in experimental studies across various malignancies ${ }^{[75-78]}$. Analysis of microbiota can be easily conducted by using oral swab or stool and integrated into immunology-MPE research ${ }^{[79]}$.

Routy et al. ${ }^{[80]}$ observed the negative impact of antibiotics assumption during immunotherapy in terms of ORR, PFS, OS in patients with NSCLC, renal cancer, urothelial cancer. To confirm the hypothesis 
Table 3. Transcriptomic pathways envolved and potential treatment strategies for each molecular subtypes

\begin{tabular}{|c|c|c|c|c|}
\hline $\begin{array}{l}\text { Molecular } \\
\text { subtypes }\end{array}$ & $\begin{array}{l}\text { Transcriptomic } \\
\text { pathways }\end{array}$ & $\begin{array}{l}\text { Potential treatment } \\
\text { strategies }\end{array}$ & $\begin{array}{c}\text { Stroma-immune } \\
\text { microenvironment }\end{array}$ & Strategies for immunotherapy \\
\hline CMS1 (14\%) & $\begin{array}{l}\text { Immune activation } \\
\text { JAK-STAT activation }\end{array}$ & $\begin{array}{l}\text { (1) Immune } \\
\text { checkpoint } \\
\text { inhibition } \\
\text { (2) Anti PD-1 + anti } \\
\text { CTLA-4/anti-IDO }\end{array}$ & $\begin{array}{l}\text { Highly } \\
\text { immunogenic }\end{array}$ & $\begin{array}{l}\text { Immune checkpoint inhibition (anti PD1/ } \\
\text { PDL-1/ anti-CTLA-4/anti-IDO) }\end{array}$ \\
\hline CMS2 (37\%) & $\begin{array}{l}\text { WNT targets } \\
\text { MYC activation } \\
\text { EGFR activation } \\
\text { VEGF or VEGFR } \\
\text { activation } \\
\text { Integrins activation } \\
\text { TGF } \beta \text { activation }\end{array}$ & $\begin{array}{l}\text { (1) Pan-RAS + } \\
\text { BRAF + PI3K wt: } \\
\text { polichemotherapy + } \\
\text { anti-EGFR } \\
\text { (2) BRAF mutated: } \\
\text { BRAF inhibitor + } \\
\text { anti-EGFR + MEK- } \\
\text { inhibitor }\end{array}$ & $\begin{array}{l}\text { Poorly } \\
\text { immunogenic }\end{array}$ & $\begin{array}{l}\text { (1) Combined EGFR pathway } \\
\text { inhibition and immune } \\
\text { checkpoint inhibition } \\
\text { (2) Combined HDAC inhibitors } \\
\text { and immune checkpoint } \\
\text { inhibition } \\
\text { (3) Immuno-chemotherapy }\end{array}$ \\
\hline CMS3 (13\%) & $\begin{array}{l}\text { DNA damage repair } \\
\text { Glutaminolysis } \\
\text { Lipidogenesis } \\
\text { Cell cycle }\end{array}$ & $\begin{array}{l}\text { (3) HER-2 amplified: } \\
\text { anti-HER2 + anti- } \\
\text { EGFR } \\
\text { (4) KRAS or } \\
\text { NRAS mutated: } \\
\text { polichemotherapy + } \\
\text { anti-VEGF }\end{array}$ & $\begin{array}{l}\text { Poorly } \\
\text { immunogenic }\end{array}$ & $\begin{array}{l}\text { (1) Combined MEK-inhibitor and } \\
\text { immune checkpoint inhibition } \\
\text { (2) Combined HDAC inhibitors } \\
\text { and immune checkpoint } \\
\text { inhibition } \\
\text { (3) Immuno-chemotherapy }\end{array}$ \\
\hline CMS4 (23\%) & $\begin{array}{l}\text { Mesenchymal } \\
\text { transition } \\
\text { Complement } \\
\text { activation } \\
\text { Immunosuppression }\end{array}$ & $\begin{array}{l}\text { (1) Polichemotherapy } \\
+ \text { anti-VEGF } \\
\text { (2) Chemotherapy + } \\
\text { anti-TGFR }\end{array}$ & $\begin{array}{l}\text { Inflamed (immune } \\
\text { tollerant) }\end{array}$ & $\begin{array}{l}\text { (1) Combined TGF pathway } \\
\text { inhibition and immune } \\
\text { checkpoint inhibition } \\
\text { (2) Combined anti-VEGF } \\
\text { and immune checkpoint } \\
\text { inhibitors } \\
\text { (3) Anti-T-reg and/or anti-MDSCs } \\
\text { treatment }\end{array}$ \\
\hline
\end{tabular}

CMS: consensus molecular subtypes; EGFR: epidermal growth factor receptor; JAK: Janus kinase; STAT: signal transducer and activator of transcription; TGF $\beta$ : transforming growth factor- $\beta$; VEGF: vascular endothelial growth factor; VEGFR: VEGF receptor; PD1: programmed death protein 1; CTLA4: cytotoxic T-Iymphocyte-associated protein 4; IDO1: indoleamine-pyrrole 2,3-dioxygenase; HDAC: histone deacetylase; MEK: mitogen-activated protein kinase (MAPK) kinase; MDSCs: myeloid derived suppressor cells

that dysbiosis might affect the therapeutic efficacy of immune check-point inhibitors, they explored the composition of gut microbioma of these patients and observed that Akkermansia muciniphila was overrepresented in the faeces of patients who later benefited from PD-1 inhibition.

Furthermore, they observed improving CPIs efficacy and increasing CCR9+CXCR3+CD4+ TILs levels when they transplanted faecal microbiota from cancer patients who responded to immunotherapy into antibioticfree mice ${ }^{[80]}$.

\section{MOLECULAR DRIVEN THERAPEUTIC HYPOTESIS}

With the CMS classification system, approximately $85 \%$ of colorectal cancers could be molecularly classified. The evolution of precision medicine should be based on association of molecular information (mutations, methylation status, gene regulation), biological and clinical characteristics of the tumour [Table 3].

Early-stage patients with CMS1 tumours and in particular MSI tumours (most CMS1 cancers) have good prognosis with low recurrence rate. No adjuvant therapy should be considered for stage II tumours, while for stage III MSI-H CRC it is plausible that the addition of oxaliplatin could overcome the potential detrimental effect of fluoropyirimide monotherapy ${ }^{[81]}$. For these subgroups of patients with MSI, hypermutated, hypermethylated cancers characterized by strong infiltration of immune cells, the usefulness of immune check-point inhibitors as the main treatment of advanced disease should be considered. Recently Shin et al. ${ }^{[82]}$ identified acquired mutations in 4 patients treated with pembrolizumab with previous clinical benefit: these mutations caused mistakes in antigen presentation and immune escape of cancer cells. New efforts should 
be done in investigating mechanisms of innate or acquired resistance to immunotherapy in these subgroups of tumours.

CMS2 cancers have low mutation rate compared to CMS1 and in most cases no mutations of BRAF and RAS are detected. Typically MYC and WNT pathways are activated so multiple efforts to interact with these signal transduction cascades should be considered ${ }^{[6]}$. For patients with KRAS, NRAS, BRAF and PIK3CA wild-type tumours (almost 30\% of all cases), anti-EGFR antibody in combination with chemotherapy should remain the standard of care though retrospective analysis from the main phase III trials suggested differential benefit of anti-EGFR treatment according to primary tumour sidedness ${ }^{[83,84]}$. Anti-EGFR benefit seems to be restricted to patients with distal primary tumor with overexpression of EGFR ligands and amplifications of EGFR and IRS2 ${ }^{[85]}$.

CMS3 cancers are characterized by KRAS mutations (almost 68\%) and enriched for multiple metabolism signatures including glutamine, fatty acid and lysophospholipid metabolism ${ }^{[6]}$. Most CMS3 cancers don't have an easily identifiable therapeutic target but trials ongoing are evaluating the potential inhibition of these metabolic processes with glycolysis inhibitors such as inhibitors of glycogen synthase kinase or inhibitors of pyruvate dehydrogenase kinases. For tumours with HER-2 overexpression (3\%-5\% of this group), anti-HER2 and pan-ERBB TKI combination should overcome primary resistance to anti-EGFR treatment. Furthermore, in KRAS mutated cell lines, preclinical trials suggested that combination of pan-RAF and MEK inhibitors may be considered ${ }^{[47]}$.

As mentioned above, CMS2 and CMS3 tumours are so called "cold" or immune-ignorant tumours. Multiple clinical trials are evaluating combinations of chemo-immunotherapy and targeted agents and immunotherapy (anti MEK + anti PDL-1, CEA-CD3 TCB + anti PDL-1, anti-EGFR + anti-PD1) after negative results of previous trials with anti-PD1 and anti-PDL1 as monotherapy. Some interesting suggestions with COX-inhibitors, HDAC inhibitors should be confirmed by future phase III trials.

For CMS4 group, the identification of actionable targets is of major interest considering the worse relapsefree and overall survival. These tumours, characterized by mesenchymal stem-cell features, seems to have no benefit from standard adjuvant therapy with 5-FU and oxaliplatin because of EMT activation ${ }^{[86]}$.

For BRAF mutated tumours, target combination therapies with BRAF-inhibitors and MEK-inhibitors have shown lower clinical benefit than in melanoma ${ }^{[87]}$. In a recent clinical experience by Kopetz et al ${ }^{[88]}$, the addition of anti-EGFR to the previous combination seems to be more effective.

Combinations of TGFR inhibitors and chemotherapy are under evaluation in ongoing clinical trials for tumours with "TGF-B activated" signature. The pro-cancerogenic effect of TGF-B develops through a direct effect on cancer cells but also on immune cells with inhibition of CTLs and NK cells associated with an expansion of Treg cells and MDSCs. In preclinical trials, combination of TGFR-B inhibitor with an OX40 agonistic $\mathrm{mAb}$ or with anti-PD1, showed a potential synergistic effect with high tumour-specific IFN $\gamma$ esponse $^{[89]}$.

Another possible target could be angiogenesis: the subgroup analysis of CALGB 80404 trial confirmed clinical benefit with bevacizumab especially in CMS4 group ${ }^{[40]}$. Furthermore retrospective analysis from Correct trial with Regorafenib (multiple TKIs that targets VEGFR1-2-3) highlighted CMS4 group as the one who benefits the most from this treatment ${ }^{[90]}$.

The efficacy of check-point inhibitors in this subgroup of patients is limited by the intense immunosuppressive response in the tumour microenvironment. 
Alternative approaches to enhance the immunotherapy efficacy in this subgroup of patients that are under evaluation, include blockade of immunosuppressive chemokine signalling circuits and pathways or elimination of MDSCs as observed in other neoplastic setting with immunosuppressive microenvironment ${ }^{[00,91]}$.

\section{CONCLUSIONS AND FUTURE PERSPECTIVES}

The development of immunotherapeutic agents has opened the way to a new era in the treatment of many solid tumors, such as renal cell carcinoma, melanoma, bladder or non-small cell lung cancer. However, despite tangible improvements in the prognosis of these malignancies, in most cases acquired resistance finally develops and leads to significant clinical progression and death. Therefore, researchers have focused primarily on the identification of the molecular bases that underlie the development of resistance in patients treated with immunotherapy. Immune checkpoint inhibitors, such as anti-PD1 and anti-PD-L1, are the most utilized among immunotherapeutic agents in the treatment of a broad spectrum of malignancies. In the near future, uncovering the molecular mechanisms responsible for primary and acquired resistance to these agents will certainly be of paramount importance. Firstly, it might allow a more accurate selection of patients who are less suitable candidate to receive immunotherapy, thus leading to a more rational allocation of the economic resources. As of today, basic research has focused primarily on PD-L1 expression as a potential predictive biomarker of response to anti-PD1 and anti-PD-L1, but, in most of the cases, it is far away from being defined a reliable biomarker. Secondly, by identifying the mechanisms underlying acquired resistance, it might be possible to develop potential strategies to overcome them.

In the era of precision medicine, the recent consensus on molecular classification of CRC has paved the way to a more personalized approach in the treatment of this disease, especially in the metastatic setting. In particular, it is now established that patients with CMS1 subtypes CRC (mainly MSI-H) are the best candidate for immunotherapy, with clinical trials demonstrating unprecedented results that lead to regulatory approval of pembrolizumab and nivolumab. Nevertheless, some clinical challenges need to be addressed in the near future in the treatment of MSI-H CRC. Firstly, as mentioned above, we need to understand why some patients are primarily resistant to these drugs and the molecular mechanisms of the development of secondary resistance. Secondly, it might be crucial to explore the role of immunotherapy in other settings, such as in the prevention of CRC, in the conversion therapy of potentially resectable liver metastases, in the adjuvant treatment of early-stage disease or in the neoadjuvant treatment of locally advanced rectal cancer.

However, MSI represents unfortunately an hallmark of a small fraction of patients with metastatic CRC. Therefore, one of the major challenges that researchers need to face in the next few years is to define strategies to convert immune-ignorant tumors (like CMS-2 and CMS-3 subgroups) into inflamed ones and to restore a "CMS-1 like" immune microenvironment in CMS-4 tumors. Many clinical trials are ongoing with new combination therapies. The results of these trials will hopefully help clinicians to abandon the therapeutic paradigm of 'one size fits all' and allow a more selective biomarkers-driven approach.

Therefore, now that immunotherapy revolution has begun with a "new kid on the block" in the therapeutic armamentarium of patients with CRC, enrollment in these clinical trials is largely encouraged.

\section{DECLARATIONS}

\section{Authors' contributions}

Conceived and designed the manuscript: Spallanzani A, Gelsomino F, Caputo F, Santini C Analysed and interpreted the data, drafted the article, revised it critically for important intellectual content and finally approved the version to be submitted: all authors 


\section{Availability of data and materials}

Not applicable.

\section{Financial support and sponsorship}

None.

\section{Conflicts of interest}

All authors declare that there are no conflicts of interest.

\section{Ethical approval and consent to participate}

Not applicable.

\section{Consent for publication}

Not applicable.

\section{Copyright}

(c) The Author(s) 2018.

\section{REFERENCES}

1. Siegel RL, Miller KD, Fedewa SA, Ahnen DJ, Meester RGS, Barzi A, Jemal A. Colorectal cancer statistics, 2017. CA Cancer J Clin 2017;67:177-93.

2. Arnold M, Sierra MS, Laversanne M, Soerjomataram I, Jemal A, Bray F. Global patterns and trends in colorectal cancer incidence and mortality. Gut 2017;66:683-91.

3. Welch HG, Robertson DJ. Colorectal cancer on the decline--why screening can't explain it all. N Engl J Med 2016;374:1605-7.

4. Cremolini C, Schirripa M, Antoniotti C, Moretto R, Salvatore L, Masi G, Falcone A, Loupakis F. First-line chemotherapy for mCRC-a review and evidence-based algorithm. Nat Rev Clin Oncol 2015;12:607-19.

5. Roelands J, Kuppen PJK, Vermeulen L, Maccalli C, Decock J, Wang E, Marincola FM, Bedognetti D, Hendrickx W. Immunogenomic classification of colorectal cancer and therapeutic implications. Int J Mol Sci 2017;18:E2229.

6. Guinney J, Dienstmann R, Wang X, de Reynies A, Schlicker A, Soneson C, Marisa L, Roepman P, Nyamundanda G, Angelino P, Bot BM, Morris JS, Simon IM, Gerster S, Fessler E, De Sousa EMF, Missiaglia E, Ramay H, Barras D, Homicsko K, Maru D, Manyam GC, Broom B, Boige V, Perez-Villamil B, Laderas T, Salazar R, Gray JW, Hanahan D, Tabernero J, Bernards R, Friend SH, Laurent-Puig P, Medema JP, Sadanandam A, Wessels L, Delorenzi M, Kopetz S, Vermeulen L, Tejpar S. The consensus molecular subtypes of colorectal cancer. Nat Med 2015;21:1350-6.

7. Markman JL, Shiao SL. Impact of the immune system and immunotherapy in colorectal cancer. J Gastrointest Oncol 2015;6:208-23.

8. Burnet FM. The concept of immunological surveillance. Prog Exp Tumor Res 1970;13:1-27.

9. Dunn GP, Old LJ, Schreiber RD. The three Es of cancer immunoediting. Annu Rev Immunol 2004;22:329-60.

10. Schreiber RD, Old LJ, Smyth MJ. Cancer immunoediting: integrating immunity's roles in cancer suppression and promotion. Science 2011;331:1565-70.

11. Grizzi F, Basso G, Borroni EM, Cavalleri T, Bianchi P, Stifter S, Chiriva-Internati M, Malesci A, Laghi L. Evolving notions on immune response in colorectal cancer and their implications for biomarker development. Inflamm Res 2018;67:375-89.

12. Cancer Genome Atlas Research Network. Comprehensive molecular characterization of gastric adenocarcinoma. Nature 2014;513:202-9.

13. Blank C, Gajewski TF, Mackensen A. Interaction of PD-L1 on tumor cells with PD-1 on tumor-specific T cells as a mechanism of immune evasion: implications for tumor immunotherapy. Cancer Immunol Immunother 2005;54:307-14.

14. Haqq J, Howells LM, Garcea G, Metcalfe MS, Steward WP, Dennison AR. Pancreatic stellate cells and pancreas cancer: current perspectives and future strategies. Eur J Cancer 2014;50:2570-82.

15. Mueller MM, Fusenig NE. Friends or foes - bipolar effects of the tumour stroma in cancer. Nat Rev Cancer 2004;4:839-49.

16. Herrera M, Herrera A, Dominguez G, Silva J, Garcia V, Garcia JM, Gomez I, Soldevilla B, Munoz C, Provencio M, Campos-Martin Y, Garcia de Herreros A, Casal I, Bonilla F, Pena C. Cancer-associated fibroblast and M2 macrophage markers together predict outcome in colorectal cancer patients. Cancer Sci 2013;104:437-44.

17. Fridman WH, Pages F, Sautes-Fridman C, Galon J. The immune contexture in human tumours: impact on clinical outcome. Nat Rev Cancer 2012;12:298-306.

18. Chen J, Chen Z. The effect of immune microenvironment on the progression and prognosis of colorectal cancer. Med Oncol 2014;31:82.

19. Galon J, Mlecnik B, Bindea G, Angell HK, Berger A, Lagorce C, Lugli A, Zlobec I, Hartmann A, Bifulco C, Nagtegaal ID, Palmqvist R, Masucci GV, Botti G, Tatangelo F, Delrio P, Maio M, Laghi L, Grizzi F, Asslaber M, D’Arrigo C, Vidal-Vanaclocha F, Zavadova E, Chouchane L, Ohashi PS, Hafezi-Bakhtiari S, Wouters BG, Roehrl M, Nguyen L, Kawakami Y, Hazama S, Okuno K, Ogino S, Gibbs P, Waring P, Sato N, Torigoe T, Itoh K, Patel PS, Shukla SN, Wang Y, Kopetz S, Sinicrope FA, Scripcariu V, Ascierto PA, Marincola FM, Fox 
BA, Pages F. Towards the introduction of the 'Immunoscore' in the classification of malignant tumours. J Pathol 2014;232:199-209.

20. Mlecnik B, Bindea G, Kirilovsky A, Angell HK, Obenauf AC, Tosolini M, Church SE, Maby P, Vasaturo A, Angelova M, Fredriksen T, Mauger S, Waldner M, Berger A, Speicher MR, Pages F, Valge-Archer V, Galon J. The tumor microenvironment and Immunoscore are critical determinants of dissemination to distant metastasis. Sci Transl Med 2016;8:327ra26.

21. Fearon ER, Vogelstein B. A genetic model for colorectal tumorigenesis. Cell 1990;61:759-67.

22. Vogelstein B, Papadopoulos N, Velculescu VE, Zhou S, Diaz LA Jr, Kinzler KW. Cancer genome landscapes. Science 2013;339:1546-58.

23. Issa JP. CpG island methylator phenotype in cancer. Nat Rev Cancer 2004;4:988-93.

24. Jones PA, Baylin SB. The fundamental role of epigenetic events in cancer. Nat Rev Genet 2002;3:415-28.

25. Armaghany T, Wilson JD, Chu Q, Mills G. Genetic alterations in colorectal cancer. Gastrointest Cancer Res 2012;5:19-27.

26. Gruber SB, Kohlmann W. The genetics of hereditary non-polyposis colorectal cancer. J Natl Compr Canc Netw 2003;1:137-44.

27. Gelsomino F, Barbolini M, Spallanzani A, Pugliese G, Cascinu S. The evolving role of microsatellite instability in colorectal cancer: a review. Cancer Treat Rev 2016;51:19-26.

28. Boland CR, Thibodeau SN, Hamilton SR, Sidransky D, Eshleman JR, Burt RW, Meltzer SJ, Rodriguez-Bigas MA, Fodde R, Ranzani GN, Srivastava S. A National Cancer Institute Workshop on Microsatellite Instability for cancer detection and familial predisposition: development of international criteria for the determination of microsatellite instability in colorectal cancer. Cancer Res 1998;58:5248-57.

29. Roepman P, Schlicker A, Tabernero J, Majewski I, Tian S, Moreno V, Snel MH, Chresta CM, Rosenberg R, Nitsche U, Macarulla T, Capella G, Salazar R, Orphanides G, Wessels LF, Bernards R, Simon IM. Colorectal cancer intrinsic subtypes predict chemotherapy benefit, deficient mismatch repair and epithelial-to-mesenchymal transition. Int J Cancer 2014;134:552-62.

30. Budinska E, Popovici V, Tejpar S, D’Ario G, Lapique N, Sikora KO, Di Narzo AF, Yan P, Hodgson JG, Weinrich S, Bosman F, Roth A, Delorenzi M. Gene expression patterns unveil a new level of molecular heterogeneity in colorectal cancer. J Pathol 2013;231:63-76.

31. Schlicker A, Beran G, Chresta CM, McWalter G, Pritchard A, Weston S, Runswick S, Davenport S, Heathcote K, Castro DA, Orphanides G, French T, Wessels LF. Subtypes of primary colorectal tumors correlate with response to targeted treatment in colorectal cell lines. BMC Med Genomics 2012;5:66.

32. Sadanandam A, Lyssiotis CA, Homicsko K, Collisson EA, Gibb WJ, Wullschleger S, Ostos LC, Lannon WA, Grotzinger C, Del Rio M, Lhermitte B, Olshen AB, Wiedenmann B, Cantley LC, Gray JW, Hanahan D. A colorectal cancer classification system that associates cellular phenotype and responses to therapy. Nat Med 2013;19:619-25.

33. Marisa L, de Reynies A, Duval A, Selves J, Gaub MP, Vescovo L, Etienne-Grimaldi MC, Schiappa R, Guenot D, Ayadi M, Kirzin S, Chazal M, Flejou JF, Benchimol D, Berger A, Lagarde A, Pencreach E, Piard F, Elias D, Parc Y, Olschwang S, Milano G, Laurent-Puig P, Boige V. Gene expression classification of colon cancer into molecular subtypes: characterization, validation, and prognostic value. PLoS Med 2013;10:e1001453.

34. De Sousa EMF, Wang X, Jansen M, Fessler E, Trinh A, de Rooij LP, de Jong JH, de Boer OJ, van Leersum R, Bijlsma MF, Rodermond H, van der Heijden M, van Noesel CJ, Tuynman JB, Dekker E, Markowetz F, Medema JP, Vermeulen L. Poor-prognosis colon cancer is defined by a molecularly distinct subtype and develops from serrated precursor lesions. Nat Med 2013;19:614-8.

35. Llosa NJ, Cruise M, Tam A, Wicks EC, Hechenbleikner EM, Taube JM, Blosser RL, Fan H, Wang H, Luber BS, Zhang M, Papadopoulos N, Kinzler KW, Vogelstein B, Sears CL, Anders RA, Pardoll DM, Housseau F. The vigorous immune microenvironment of microsatellite instable colon cancer is balanced by multiple counter-inhibitory checkpoints. Cancer Discov 2015;5:43-51.

36. Tran B, Kopetz S, Tie J, Gibbs P, Jiang ZQ, Lieu CH, Agarwal A, Maru DM, Sieber O, Desai J. Impact of BRAF mutation and microsatellite instability on the pattern of metastatic spread and prognosis in metastatic colorectal cancer. Cancer 2011;117:4623-32.

37. Gavin PG, Colangelo LH, Fumagalli D, Tanaka N, Remillard MY, Yothers G, Kim C, Taniyama Y, Kim SI, Choi HJ, Blackmon NL, Lipchik C, Petrelli NJ, O'Connell MJ, Wolmark N, Paik S, Pogue-Geile KL. Mutation profiling and microsatellite instability in stage II and III colon cancer: an assessment of their prognostic and oxaliplatin predictive value. Clin Cancer Res 2012;18:6531-41.

38. Popovici V, Budinska E, Bosman FT, Tejpar S, Roth AD, Delorenzi M. Context-dependent interpretation of the prognostic value of BRAF and KRAS mutations in colorectal cancer. BMC Cancer 2013;13:439.

39. Colle R, Cohen R, Cochereau D, Duval A, Lascols O, Lopez-Trabada D, Afchain P, Trouilloud I, Parc Y, Lefevre JH, Flejou JF, Svrcek M, Andre T. Immunotherapy and patients treated for cancer with microsatellite instability. Bull Cancer 2017;104:42-51.

40. Lenz HJ, Ou FS, Venook AP, Hochster HS, Niedzwiecki D, Goldberg RM, Mayer RJ, Bertagnolli MM, Blanke CD, Zemla T, Qu X, Innocenti F, Kabbarah O. Impact of consensus molecular subtyping (CMS) on overall survival (OS) and progression free survival (PFS) in patients (pts) with metastatic colorectal cancer (mCRC): analysis of CALGB/SWOG 80405 (Alliance). J Clin Oncol 2017;35 Suppl 15:abstr3511.

41. Chung KY, Gore I, Fong L, Venook A, Beck SB, Dorazio P, Criscitiello PJ, Healey DI, Huang B, Gomez-Navarro J, Saltz LB. Phase II study of the anti-cytotoxic T-lymphocyte-associated antigen 4 monoclonal antibody, tremelimumab, in patients with refractory metastatic colorectal cancer. J Clin Oncol 2010;28:3485-90.

42. Le DT, Uram JN, Wang H, Bartlett BR, Kemberling H, Eyring AD, Skora AD, Luber BS, Azad NS, Laheru D, Biedrzycki B, Donehower RC, Zaheer A, Fisher GA, Crocenzi TS, Lee JJ, Duffy SM, Goldberg RM, de la Chapelle A, Koshiji M, Bhaijee F, Huebner T, Hruban RH, Wood LD, Cuka N, Pardoll DM, Papadopoulos N, Kinzler KW, Zhou S, Cornish TC, Taube JM, Anders RA, Eshleman JR, Vogelstein B, Diaz LA Jr. PD-1 blockade in tumors with mismatch-repair deficiency. N Engl J Med 2015;372:2509-20.

43. Overman MJ, McDermott R, Leach JL, Lonardi S, Lenz HJ, Morse MA, Desai J, Hill A, Axelson M, Moss RA, Goldberg MV, Cao ZA, Ledeine JM, Maglinte GA, Kopetz S, Andre T. Nivolumab in patients with metastatic DNA mismatch repair-deficient or microsatellite instability-high colorectal cancer (CheckMate 142): an open-label, multicentre, phase 2 study. Lancet Oncol 2017;18:1182-91.

44. Overman MJ, Lonardi S, Wong KYM, Lenz HJ, Gelsomino F, Aglietta M, Morse MA, Van Cutsem E, McDermott R, Hill A, Sawyer MB, Hendlisz A, Neyns B, Svrcek M, Moss RA, Ledeine JM, Cao ZA, Kamble S, Kopetz S, Andre T. Durable clinical benefit with nivolumab plus ipilimumab in DNA mismatch repair-deficient/microsatellite instability-high metastatic colorectal cancer. J Clin Oncol 2018;36:773-9.

45. Topalian SL, Hodi FS, Brahmer JR, Gettinger SN, Smith DC, McDermott DF, Powderly JD, Carvajal RD, Sosman JA, Atkins MB, Leming 
PD, Spigel DR, Antonia SJ, Horn L, Drake CG, Pardoll DM, Chen L, Sharfman WH, Anders RA, Taube JM, McMiller TL, Xu H, Korman AJ, Jure-Kunkel M, Agrawal S, McDonald D, Kollia GD, Gupta A, Wigginton JM, Sznol M. Safety, activity, and immune correlates of antiPD-1 antibody in cancer. N Engl J Med 2012;366:2443-54.

46. Brahmer JR, Tykodi SS, Chow LQ, Hwu WJ, Topalian SL, Hwu P, Drake CG, Camacho LH, Kauh J, Odunsi K, Pitot HC, Hamid O, Bhatia S, Martins R, Eaton K, Chen S, Salay TM, Alaparthy S, Grosso JF, Korman AJ, Parker SM, Agrawal S, Goldberg SM, Pardoll DM, Gupta A, Wigginton JM. Safety and activity of anti-PD-L1 antibody in patients with advanced cancer. N Engl J Med 2012;366:2455-65.

47. Dienstmann R, Vermeulen L, Guinney J, Kopetz S, Tejpar S, Tabernero J. Consensus molecular subtypes and the evolution of precision medicine in colorectal cancer. Nat Rev Cancer 2017;17:268.

48. Schaer DA, Hirschhorn-Cymerman D, Wolchok JD. Targeting tumor-necrosis factor receptor pathways for tumor immunotherapy. J Immunother Cancer 2014;2:7.

49. Bendell JC, Powderly J, Lieu CH, Eckhardt SG, Hurwitz H, Hochster HS, Murphy JE, Funke RP, Rossi C, Wallin J, Waterkamp D, Pishvaian MJ. Safety and efficacy of MPDL3280A (anti-PDL1) in combination with bevacizumab (bev) and/or FOLFOX in patients (pts) with metastatic colorectal cancer (mCRC). J Clin Oncol 2015;33 Suppl 3:abstr704.

50. Limagne E, Euvrard R, Thibaudin M, Rebe C, Derangere V, Chevriaux A, Boidot R, Vegran F, Bonnefoy N, Vincent J, Bengrine-Lefevre L, Ladoire S, Delmas D, Apetoh L, Ghiringhelli F. Accumulation of MDSC and Th17 cells in patients with metastatic colorectal cancer predicts the efficacy of a FOLFOX-bevacizumab drug treatment regimen. Cancer Res 2016;76:5241-52.

51. Ebert PJR, Cheung J, Yang Y, McNamara E, Hong R, Moskalenko M, Gould SE, Maecker H, Irving BA, Kim JM, Belvin M, Mellman I MAP kinase inhibition promotes T cell and anti-tumor activity in combination with PD-L1 checkpoint blockade. Immunity 2016;44:609-21.

52. Hatzivassiliou G, Haling JR, Chen H, Song K, Price S, Heald R, Hewitt JF, Zak M, Peck A, Orr C, Merchant M, Hoeflich KP, Chan J, Luoh SM, Anderson DJ, Ludlam MJ, Wiesmann C, Ultsch M, Friedman LS, Malek S, Belvin M. Mechanism of MEK inhibition determines efficacy in mutant KRAS- versus BRAF-driven cancers. Nature 2013;501:232-6.

53. Bendell JC, Kim TW, Goh BC, Wallin J, Oh DY, Han SW, Lee CB, Hellmann MD, Desai JM, Lewin JH, Solomon BJ, Chow LQM, Miller WH, Gainor JF, Flaherty K, Infante JR, Das-Thakur M, Foster P, Cha E, Bang YJ. Clinical activity and safety of cobimetinib and atezolizumab in colorectal cancer. J Clin Oncol 2016;34 Suppl 15:abstr3502.

54. Zheng H, Zhao W, Yan C, Watson CC, Massengill M, Xie M, Massengill C, Noyes DR, Martinez GV, Afzal R, Chen Z, Ren X, Antonia SJ, Haura EB, Ruffell B, Beg AA. HDAC inhibitors enhance T-cell chemokine expression and augment response to PD-1 immunotherapy in lung adenocarcinoma. Clin Cancer Res 2016;22:4119-32.

55. Bacac M, Fauti T, Sam J, Colombetti S, Weinzierl T, Ouaret D, Bodmer W, Lehmann S, Hofer T, Hosse RJ, Moessner E, Ast O, Bruenker P, Grau-Richards S, Schaller T, Seidl A, Gerdes C, Perro M, Nicolini V, Steinhoff N, Dudal S, Neumann S, von Hirschheydt T, Jaeger C, Saro J, Karanikas V, Klein C, Umana P. A novel carcinoembryonic antigen T-cell bispecific antibody (CEA TCB) for the treatment of solid tumors. Clin Cancer Res 2016;22:3286-97.

56. Bacac M, Klein C, Umana P. CEA TCB: a novel head-to-tail 2:1 T cell bispecific antibody for treatment of CEA-positive solid tumors. Oncoimmunology 2016;5:e1203498.

57. Tabernero J, Melero I, Ros W, Argiles G, Marabelle A, Rodriguez-Ruiz ME, Albanell J, Calvo E, Moreno V, Cleary JM, Eder JP, Karanikas V, Bouseida S, Sandoval F, Sabanes D, Sreckovic S, Hurwitz H, Paz-Ares LG, Saro Suarez JM, Segal NH. Phase Ia and Ib studies of the novel carcinoembryonic antigen (CEA) T-cell bispecific (CEA CD3 TCB) antibody as a single agent and in combination with atezolizumab: Preliminary efficacy and safety in patients with metastatic colorectal cancer (mCRC). J Clin Oncol 2017;35 Suppl 15:abstr3002.

58. Mole RH. Whole body irradiation; radiobiology or medicine? Br J Radiol 1953;26:234-41.

59. Sharma A, Bode B, Wenger RH, Lehmann K, Sartori AA, Moch H, Knuth A, Boehmer L, Broek M. Gamma-Radiation promotes immunological recognition of cancer cells through increased expression of cancer-testis antigens in vitro and in vivo. PLoS One 2011;6:e28217.

60. Park SS, Dong H, Liu X, Harrington SM, Krco CJ, Grams MP, Mansfield AS, Furutani KM, Olivier KR, Kwon ED. PD-1 restrains radiotherapy-induced abscopal effect. Cancer Immunol Res 2015;3:610-9.

61. Segal NH, Kemeny NE, Cercek A, Reidy DL, Raasch PJ, Warren P, Hrabovsky AE, Campbell N, Shia J, Goodman KA, Erinjeri JP, Solomon SB, Yamada Y, Saltz L. Non-randomized phase II study to assess the efficacy of pembrolizumab (Pem) plus radiotherapy (RT) or ablation in mismatch repair proficient (pMMR) metastatic colorectal cancer (mCRC) patients. J Clin Oncol 2016;34 Suppl 15:abstr3539.

62. Beatty GL, O’Dwyer PJ, Clark J, Shi JG, Bowman KJ, Scherle PA, Newton RC, Schaub R, Maleski J, Leopold L, Gajewski TF. First-inhuman phase I study of the oral inhibitor of indoleamine 2,3-dioxygenase-1 epacadostat (INCB024360) in patients with advanced solid malignancies. Clin Cancer Res 2017;23:3269-76.

63. Gangadhar TC, Hamid O, Smith DC, Bauer TM, Wasser AC, Olszanski AS, Luke JJ, Balmanoukian AS, Kaufman DR, Zhao Y, Maleski J, Jones MJ, Leopold L Gajewski TF. Epacadostat plus pembrolizumab in patients with advance melanoma and select solid tumors: Updated phase 1 results from ECHO-202/KEYNOTE-037. Ann Oncol 2016;27 suppl 6:1110PD.

64. Srivastava RM, Lee SC, Andrade Filho PA, Lord CA, Jie HB, Davidson HC, Lopez-Albaitero A, Gibson SP, Gooding WE, Ferrone S, Ferris RL. Cetuximab-activated natural killer and dendritic cells collaborate to trigger tumor antigen-specific T-cell immunity in head and neck cancer patients. Clin Cancer Res 2013;19:1858-72.

65. Basile D, Garattini SK, Bonotto M, Ongaro E, Casagrande M, Cattaneo M, Fanotto V, De Carlo E, Loupakis F, Urbano F, Negri FV, Pella N, Russano M, Brunetti O, Scartozzi M, Santini D, Silvestris N, Casadei Gardini A, Puzzoni M, Calvetti L, Cardarelli N, Aprile G. Immunotherapy for colorectal cancer: where are we heading? Expert Opin Biol Ther 2017;17:709-21.

66. Wittig B, Schmidt M, Scheithauer W, Schmoll HJ. MGN1703, an immunomodulator and toll-like receptor 9 (TLR-9) agonist: from bench to bedside. Crit Rev Oncol Hematol 2015;94:31-44.

67. Schmoll HJ, Wittig B, Arnold D, Riera-Knorrenschild J, Nitsche D, Kroening H, Mayer F, Andel J, Ziebermayr R, Scheithauer W. Maintenance treatment with the immunomodulator MGN1703, a Toll-like receptor 9 (TLR9) agonist, in patients with metastatic colorectal carcinoma and disease control after chemotherapy: a randomised, double-blind, placebo-controlled trial. J Cancer Res Clin Oncol 
2014;140:1615-24.

68. Brivio F, Lissoni P, Alderi G, Barni S, Lavorato F, Fumagalli L. Preoperative interleukin-2 subcutaneous immunotherapy may prolong the survival time in advanced colorectal cancer patients. Oncology 1996;53:263-8.

69. Kimura T, McKolanis JR, Dzubinski LA, Islam K, Potter DM, Salazar AM, Schoen RE, Finn OJ. MUC1 vaccine for individuals with advanced adenoma of the colon: a cancer immunoprevention feasibility study. Cancer Prev Res (Phila) 2013;6:18-26.

70. Carbone DP, Ciernik IF, Kelley MJ, Smith MC, Nadaf S, Kavanaugh D, Maher VE, Stipanov M, Contois D, Johnson BE, Pendleton CD, Seifert B, Carter C, Read EJ, Greenblatt J, Top LE, Kelsey MI, Minna JD, Berzofsky JA. Immunization with mutant p53- and K-ras-derived peptides in cancer patients: immune response and clinical outcome. J Clin Oncol 2005;23:5099-107.

71. Fletcher R, Wang YJ, Schoen RE, Finn OJ, Yu J, Zhang L. Colorectal cancer prevention: Immune modulation taking the stage. Biochim Biophys Acta 2018;1869:138-48.

72. Frouws MA, van Herk-Sukel MPP, Maas HA, Van de Velde CJH, Portielje JEA, Liefers GJ, Bastiaannet E. The mortality reducing effect of aspirin in colorectal cancer patients: Interpreting the evidence. Cancer Treat Rev 2017;55:120-7.

73. Zelenay S, van der Veen AG, Bottcher JP, Snelgrove KJ, Rogers N, Acton SE, Chakravarty P, Girotti MR, Marais R, Quezada SA, Sahai E, Reis e Sousa C. Cyclooxygenase-dependent tumor growth through evasion of immunity. Cell 2015;162:1257-70.

74. Ogino S, Nowak JA, Hamada T, Phipps AI, Peters U, Milner DA Jr, Giovannucci EL, Nishihara R, Giannakis M, Garrett WS, Song M. Integrative analysis of exogenous, endogenous, tumour and immune factors for precision medicine. Gut 2018;67:1168-80.

75. Sivan A, Corrales L, Hubert N, Williams JB, Aquino-Michaels K, Earley ZM, Benyamin FW, Lei YM, Jabri B, Alegre ML, Chang EB, Gajewski TF. Commensal Bifidobacterium promotes antitumor immunity and facilitates anti-PD-L1 efficacy. Science 2015;350:1084-9.

76. Vetizou M, Pitt JM, Daillere R, Lepage P, Waldschmitt N, Flament C, Rusakiewicz S, Routy B, Roberti MP, Duong CP, Poirier-Colame V, Roux A, Becharef S, Formenti S, Golden E, Cording S, Eberl G, Schlitzer A, Ginhoux F, Mani S, Yamazaki T, Jacquelot N, Enot DP, Berard M, Nigou J, Opolon P, Eggermont A, Woerther PL, Chachaty E, Chaput N, Robert C, Mateus C, Kroemer G, Raoult D, Boneca IG, Carbonnel F, Chamaillard M, Zitvogel L. Anticancer immunotherapy by CTLA-4 blockade relies on the gut microbiota. Science 2015;350:1079-84.

77. Yu T, Guo F, Yu Y, Sun T, Ma D, Han J, Qian Y, Kryczek I, Sun D, Nagarsheth N, Chen Y, Chen H, Hong J, Zou W, Fang JY. Fusobacterium nucleatum promotes chemoresistance to colorectal cancer by modulating autophagy. Cell 2017;170:548-63.e16.

78. Gopalakrishnan V, Spencer CN, Nezi L, Reuben A, Andrews MC, Karpinets TV, Prieto PA, Vicente D, Hoffman K, Wei SC, Cogdill AP, Zhao L, Hudgens CW, Hutchinson DS, Manzo T, Petaccia de Macedo M, Cotechini T, Kumar T, Chen WS, Reddy SM, Szczepaniak Sloane R, Galloway-Pena J, Jiang H, Chen PL, Shpall EJ, Rezvani K, Alousi AM, Chemaly RF, Shelburne S, Vence LM, Okhuysen PC, Jensen VB, Swennes AG, McAllister F, Marcelo Riquelme Sanchez E, Zhang Y, Le Chatelier E, Zitvogel L, Pons N, Austin-Breneman JL, Haydu LE, Burton EM, Gardner JM, Sirmans E, Hu J, Lazar AJ, Tsujikawa T, Diab A, Tawbi H, Glitza IC, Hwu WJ, Patel SP, Woodman SE, Amaria RN, Davies MA, Gershenwald JE, Hwu P, Lee JE, Zhang J, Coussens LM, Cooper ZA, Futreal PA, Daniel CR, Ajami NJ, Petrosino JF, Tetzlaff MT, Sharma P, Allison JP, Jenq RR, Wargo JA. Gut microbiome modulates response to anti-PD-1 immunotherapy in melanoma patients. Science 2018;359:97-103.

79. Rajpoot M, Sharma AK, Sharma A, Gupta GK. Understanding the microbiome: emerging biomarkers for exploiting the microbiota for personalized medicine against cancer. Semin Cancer Biol 2018; doi: 10.1016/j.semcancer.2018.02.003.

80. Routy B, Le Chatelier E, Derosa L, Duong CPM, Alou MT, Daillere R, Fluckiger A, Messaoudene M, Rauber C, Roberti MP, Fidelle M, Flament C, Poirier-Colame V, Opolon P, Klein C, Iribarren K, Mondragon L, Jacquelot N, Qu B, Ferrere G, Clemenson C, Mezquita L, Masip JR, Naltet C, Brosseau S, Kaderbhai C, Richard C, Rizvi H, Levenez F, Galleron N, Quinquis B, Pons N, Ryffel B, Minard-Colin V, Gonin P, Soria JC, Deutsch E, Loriot Y, Ghiringhelli F, Zalcman G, Goldwasser F, Escudier B, Hellmann MD, Eggermont A, Raoult D, Albiges L, Kroemer G, Zitvogel L. Gut microbiome influences efficacy of PD-1-based immunotherapy against epithelial tumors. Science 2018;359:91-7.

81. Andre T, de Gramont A, Vernerey D, Chibaudel B, Bonnetain F, Tijeras-Raballand A, Scriva A, Hickish T, Tabernero J, Van Laethem JL, Banzi M, Maartense E, Shmueli E, Carlsson GU, Scheithauer W, Papamichael D, Moehler M, Landolfi S, Demetter P, Colote S, Tournigand C, Louvet C, Duval A, Flejou JF, de Gramont A. Adjuvant fluorouracil, leucovorin, and oxaliplatin in stage II to III colon cancer: updated 10year survival and outcomes according to BRAF mutation and mismatch repair status of the MOSAIC study. J Clin Oncol 2015;33:4176-87.

82. Shin DS, Zaretsky JM, Escuin-Ordinas H, Garcia-Diaz A, Hu-Lieskovan S, Kalbasi A, Grasso CS, Hugo W, Sandoval S, Torrejon DY, Palaskas N, Rodriguez GA, Parisi G, Azhdam A, Chmielowski B, Cherry G, Seja E, Berent-Maoz B, Shintaku IP, Le DT, Pardoll DM, Diaz LA, Jr., Tumeh PC, Graeber TG, Lo RS, Comin-Anduix B, Ribas A. Primary resistance to PD-1 blockade mediated by JAK1/2 mutations. Cancer Discov 2017;7:188-201.

83. Petrelli F, Tomasello G, Borgonovo K, Ghidini M, Turati L, Dallera P, Passalacqua R, Sgroi G, Barni S. Prognostic survival associated with left-sided vs right-sided colon cancer: a systematic review and meta-analysis. JAMA Oncol 2016; doi: 10.1001/jamaoncol.2016.4227.

84. Tejpar S, Stintzing S, Ciardiello F, Tabernero J, Van Cutsem E, Beier F, Esser R, Lenz HJ, Heinemann V. Prognostic and predictive relevance of primary tumor location in patients with RAS wild-type metastatic colorectal cancer: retrospective analyses of the CRYSTAL and FIRE-3 trials. JAMA Oncol 2016; doi: 10.1001/jamaoncol.2016.3797.

85. Seligmann JF, Elliott F, Richman SD, Jacobs B, Hemmings G, Brown S, Barrett JH, Tejpar S, Quirke P, Seymour MT. Combined epiregulin and amphiregulin expression levels as a predictive biomarker for panitumumab therapy benefit or lack of benefit in patients with RAS wildtype advanced colorectal cancer. JAMA Oncol 2016; doi: 10.1001/jamaoncol.2015.6065.

86. Song N, Pogue-Geile KL, Gavin PG, Yothers G, Kim SR, Johnson NL, Lipchik C, Allegra CJ, Petrelli NJ, O'Connell MJ, Wolmark N, Paik S. Clinical outcome from oxaliplatin treatment in stage II/III colon cancer according to intrinsic subtypes: secondary analysis of NSABP C-07/ NRG oncology randomized clinical trial. JAMA Oncol 2016;2:1162-9.

87. Corcoran RB, Atreya CE, Falchook GS, Kwak EL, Ryan DP, Bendell JC, Hamid O, Messersmith WA, Daud A, Kurzrock R, Pierobon M, Sun P, Cunningham E, Little S, Orford K, Motwani M, Bai Y, Patel K, Venook AP, Kopetz S. Combined BRAF and MEK inhibition with dabrafenib and trametinib in BRAF V600-mutant colorectal cancer. J Clin Oncol 2015;33:4023-31.

88. Kopetz S, McDonough SL, Morris VK, Lenz HJ, Magliocco AM, Atreya CE, Diaz LA, Allegra CJ, Wang SE, Lieu CH, Eckhardt SH, Semrad TJ, Kaberle K, Guthrie KA, Hochster HS. Randomized trial of irinotecan and cetuximab with or without vemurafenib in BRAF- 
mutant metastatic colorectal cancer (SWOG 1406). J Clin Oncol 2017;35 suppl 15:abstr520.

89. Triplett TA, Tucker CG, Triplett KC, Alderman Z, Sun L, Ling LE, Akporiaye ET, Weinberg AD. STAT3 signaling is required for optimal regression of large established tumors in mice treated with anti-OX40 and TGFbeta receptor blockade. Cancer Immunol Res 2015;3:526-35.

90. Teufel M, Schwenke S, Seidel H, Beckmann G, Reischl J, Vonk R, Lenz HJ, Tabernero J, Siena S, Grothey A, Van Cutsem E, Jeffers M, Wilhelm S, Wagner A, Laurent D, Kobina S, Rutstein MD, Wirapati P, Guinney J, Tejpar S. Molecular subtypes and outcomes in regorafenib-treated patients with metastatic colorectal cancer (mCRC) enrolled in the CORRECT trial. J Clin Oncol 2015;33 Suppl 15:abstr4000.

91. Wang G, Lu X, Dey P, Deng P, Wu CC, Jiang S, Fang Z, Zhao K, Konaparthi R, Hua S, Zhang J, Li-Ning-Tapia EM, Kapoor A, Wu CJ, Patel NB, Guo Z, Ramamoorthy V, Tieu TN, Heffernan T, Zhao D, Shang X, Khadka S, Hou P, Hu B, Jin EJ, Yao W, Pan X, Ding Z, Shi Y, Li L, Chang Q, Troncoso P, Logothetis CJ, McArthur MJ, Chin L, Wang YA, DePinho RA. Targeting YAP-dependent MDSC infiltration impairs tumor progression. Cancer Discov 2016;6:80-95. 